\title{
Implementing energy policies in urban development projects: The role of public planning authorities in Denmark, Germany and the Netherlands
}

\author{
Petersen, Jens-Phillip; Heurkens, Erwin
}

Published in:

Land Use Policy

Link to article, DOI:

10.1016/j.landusepol.2018.05.004

Publication date:

2018

Document Version

Early version, also known as pre-print

Link back to DTU Orbit

Citation (APA):

Petersen, J-P., \& Heurkens, E. (2018). Implementing energy policies in urban development projects: The role of public planning authorities in Denmark, Germany and the Netherlands. Land Use Policy, 76, 275-289.

https://doi.org/10.1016/j.landusepol.2018.05.004

\section{General rights}

Copyright and moral rights for the publications made accessible in the public portal are retained by the authors and/or other copyright owners and it is a condition of accessing publications that users recognise and abide by the legal requirements associated with these rights.

- Users may download and print one copy of any publication from the public portal for the purpose of private study or research.

- You may not further distribute the material or use it for any profit-making activity or commercial gain

- You may freely distribute the URL identifying the publication in the public portal 


\title{
Implementing energy policies in urban development pro- jects: The role of public planning authorities in Denmark, Germany and the Netherlands
}

\author{
J ens-Phillip Petersen ${ }^{a *}$ and Erwin Heurkens ${ }^{b}$ \\ a Department of Civil Engineering (ICIEE), Technical University Denmark \\ b Department Management in the Built Environment, Delft University of Technology
}

Governing climate mitigation is complex, as the recurring gap between policy intentions and actions exhibits. Interventions at the urban scale represent an opportunity to implement energy policy targets. Urban development projects can function as carrier to implement innovative energy solutions as by-product'. To do so, planners must proactively and strategically deploy planning instruments to influence market behaviour, since project realization relies heavily on public-private interaction. This paper explores how local planning authorities use a variety of planning instruments in urban development projects that assist in implementing both planning and energy policy targets. To understand how planning instruments can be deployed deliberately to implement energy policy targets and why a specific instrument mix was chosen, this paper presents a cross-comparison of three urban development projects from Denmark, Germany and the Netherlands, which all successfully implemented innovative energy solutions. Results show that contextual differences in the processes entail the use of specific instruments to implement energy policy targets. However, the deployed instrument types, enabling factors and involved governmental levels in the technology-open processes showed a similar pattern across all three cases.

Keywords: Sustainable urban development, policy instruments, energy strategy implementation, planner roles

\section{Introduction}

The importance of the urban scale and local authorities for the implementation of the sustainable development agenda has been amply stressed since early climate change discussions among the wider public three decades ago (Bulkeley\& Betsill, 2005). This 'near-universal' claim has entered public policies, delegating a high ratio of the realization of global climate mitigation targets to the urban scale, since it can function as a testing ground for new approaches and innovation, where niche spaces for sustainable development paths are explorable, and where these targets should be planned and implemented by local authorities (Schroeder, Burch \&Rayner, 2013). Notably, land-use planning competencies are a powerful tool for local authorities to influence energy use (Stoeglehner \& Narodoslawsky, 2013): Through binding stipulations, abstract energy policies can manifest in concrete changes of the built environment at community scale (Bulkeley\&Betsill, 2005). The community scale - as intermediate between policy level and households (Connors \& McDonald, 2011) -is emphasised as the central arena for energy strategy implementation through the translation of abstract targets into concrete actions (Mulugetta, J ackson \&Van der Horst, 2010). All kinds of urban interventions and development projects are a potential window of opportunity to implement energy policies (Rutherford \& Coutard, 2014). 
However, the implementation is far from straightforward, since the complexity of the stressed urban scale requires comprehensive actions by various actors, scales and disciplines in taking responsibility across collaborative networks (Bulkeley \&Moser, 2007). While urban energy strategies are typically formulated at city scale, the implementation relies to a large extent on aligning activities at community scale to city scale targets (Petersen, 2018). Here, urban development projects can bea strategic tool to govern energy mitigation policies (Rydin, 2010). This is challenged by the changing roles of public authorities in pluralistic societies, where neo-liberal processes in spatial planning have led to government decentralization, retrenchments, and new modes of governance (Pierre \& Peters, 2012), leading to an increased role of private market actors in urban development policies (Heurkens \& Hobma, 2014). A major share of urban climate change experiments is already carried out by public-private partnerships (PPP), blurring the boundaries between public and private spheres (Castán Broto \& Bulkeley, 2013). Despite environmental sustainability being considered as important by public and private actors, it is still mainly seen as a by-product in urban development projects, since the main targets are of a social or economic nature (Harman, Taylor \& Lane, 2015). The regularly experienced gap between the rhetoric of climate protection and its implementation in the built environment (Bulkeley \& Betsill, 2005) has led to a non-attainment of climate mitigation targets (Vergragt, Akenji \& Dewick, 2014). A deliberate deployment of planning instruments by public authorities can be a viable option to implement energy policies in urban development projects. However, there is a general lack of understanding how this is done, since energy literature does not consider urban issues, and urban literature mutually does not consider energy issues (Rutherford \& Coutard, 2014). In this context, we want to put more explicit attention to interactions between local governments and the private sector that reconfigure the built environment in accordance to energy policies.

This paper seeks to explore how the implementation of higher-level energy policies can be achieved in urban development projects-despite only being a byproduct. Drawing on the action-oriented concept of 'plan-shaped markets' (Adams \& Tiesdell, 2010), we are interested in analysing the planners' role in deploying specific instruments to actively influence market decisions that enable the attainment of energy targets. We argue that a successful energy target implementation goes hand in hand with planners taking on an active role in shaping markets through well-informed plans, instead of just reacting to market-pressures (Heurkens, Adams \& Hobma, 2015). The likelihood of implementing energy policies as by-products in urban development projects increases if planners choose a proactive approach, retaining energy ambitions in public-private interactions. Since planners operate within a particular sociopolitical context, shaping preferences for different policy instruments, we have to be aware of the role of the underlying institutions that define the role of the planner, the available mix of planning instruments, and the way in which the development aims and energy policies are framed (Majoor \& Schwartz, 2015). The dependence of planning instruments from national institutions (Pierre \& Peters, 2012) requires cross-national analyses of similar urban development projects. 
In the next section, we provide a deeper insight into planning strategies, how planners can shape local markets that enable innovative energy solutions, planning instrument types, and which contextual factors have to be considered. Based on this we propose an analytical framework in the following methodology section. In Section 4 we examine three urban development projects from Denmark, Germany and the Netherlands to demonstrate which combination of instrument types enabled the implementation of energy policy targets. This includes the analysis of instrument choice and market effects in relation to project aims and institutional contexts. Through a cross-case comparison, lessons are drawn on the relevance of planning instruments as enablers for the implementation of energy policies in urban development projects.

\section{Theoretical background}

To attain overall societal energy policy targets, actions at all scales are necessary, which implies that all interventions in the built environment should positively contribute. A closer attention to planning instruments enabling the target implementation is required, while being aware of the dynamics in public-private actornetworks in the urban context. Urban development projects are an important arena where abstract energy policy targets can be transformed into concrete energy technology (Bulkeley\& Betsill, 2005). We claim that attaining energy targets is similar to other agendas in spatial planning. However, as abstract and relatively new agenda (Islar \& Busch, 2016), energy is often considered with lower priority than classic spatial concerns, leading to required competencies often not being at disposal (Petersen, 2018). To analyse planning instrument choices and market effects we have to consider the roles of planning entities, public-private interactions in urban development, and how these are influenced by the institutional contexts of urban development projects.

\subsection{From strategy to action: Preconditions for the implementation of energy policies}

The translation of strategic intentions of energy policies into practice is a constant challenge for any planner. The implementation of energy policy targets requires interrelated actions, often composed in spatial energy strategies. These strategies are more than a document outlining future actions to reach a desired energy target: they are the systematic organization of collective actions around goals (Bryson, 2011) involving a multitude of public and private actors. Hence, energy strategies are both a product of and an ongoing process from strategy production, over framing documents, up to the implementation of key considerations through time (Healey \& Hillier, 2008). In this understanding, real world strategies are behavioural patterns to achieve specific targets, usually found in-between deliberate plans and emergent developments, since parts of the deliberate plan stay unrealised and are replaced by emergent strategy elements (Mintzberg, Ahlstrand \& Lampel, 1998). The frequent implementation gap between energy policy ambition and practice raises the question if planners are vulnerable towards emergent market developments and 'decision-takers', or if planners can also be a proactive 'decision-makers' (Heurkens et al., 2015)? 
In market economies, public planners are seldom in a position to determine the implementation of urban development targets. We have to understand planning as 'an intervention in, or an influencing of, the creation and use of the physical environment by others' (Needham, 2000), and strategies, if seen as human interactions, as capacity to link actors with divergent interests, goals, and working procedures to realise certain goals (Daamen, 2010). The understanding, incorporation and alignment of different 'actor worlds' (Callon, 1986) requires a deliberate proceeding by proactive planners to be able to unlock and use their inherent competencies. This gains importance since the private sector and not the public is becoming 'the dominant implementation agent' in planning (Heurkens et al., 2015). Planners do have a set of planning instruments that, if deployed insistently, can influence the behaviour of semi-public and private actors to implement energy policies as by-product in urban development processes.

\subsection{The role of the planner as market actor}

Similar to an active-land policy, the implementation of energy targets requires an active-energy policy. Plans only become actions if public planners make a constant effort to merge political power with the dynamics of real estate developments in shaping, regulating and stimulating real estate markets. Planners have to realise that they are market actors, which to some extent are able to (re)construct markets using planning instruments. The implied concept of 'plan-shaped markets' sees planning and markets in a constant and dynamic interaction, so planners 'become a significant constitutive element of such markets' (Adams \& Tiesdell, 2013).

The concept offers an economic explanation and justification of planners' actions in practice (Heurkens et al., 2015)0, since real estate markets are understood as a social construct, shaped by institutional, cultural, and economic environments (Magalhães, 2013). In regard to municipal energy policy this recognition was stalled due to the prevailing 'techno-rationalist approach' (Guy \& Shove, 2000) in energy planning focusing too often on specific technical constellations as target, which are not in line with other actors' (economic) interests. In line with $\mathrm{Pe}$ tersen and Quitzau (2018), we understand implementation of energy targets as the translation of policies into viable (re)configurations of the built environment. This requires the alignment of the different stakeholder-networks that shape urban development (Rydin, 2010, p.32), which is a key task for planners. In contrast to other descriptive models of governance approaches (e.g. Rydin, 2010; Pierre \& Peters, 2012), the concept of Adams \& Tiesdell (2013) allows the assessment of causal relationships between planning, instrument use and market effects-or, in other words, actions that change the built environment in the direction of the energy targets. Hence, the model enables the assessment of the process of bridging the gap between general energy policy targets, and concrete technical solutions aligned with private market actor interests and the public targets.

However, in plan-shaped markets the realization of development targets require planners to aim for clearly specified targets (Magalhães, 2013) by the application of planning instruments in a strategic manner since they 'get people to do things that they might not otherwise do' (Schneider \& Ingram, 1990)0. The instrument choice-usually defined by costs, expected effectiveness, feasibility (Lascoumes 
\& Le Galès, 2007) — should be undertaken in regard to the extent to which their use improves a pure real estate market solution (Heurkens et al., 2015)0. To act accordingly, planners require extensive capacities beyond technical knowledge; including knowledge on the local context (planning situation, markets, and localactor networks), strategic knowledge (process design, project management), and operational knowledge (planning instruments, finances and technologies). This knowledge is often introduced to a development project by external actors ( $\mathrm{Pe}$ tersen \&Quitzau, 2018). In the case of energy policies, this allocates a crucial role to public authorities. They have to apply planning instruments strategically, acting within and influencing real estate markets that are to a great extent responsible for policy target implementation.

\subsection{Planning instruments in urban development projects}

Planners can influence market operations that implement urban development policies by using available planning instruments more efficiently. This applies to the overall urban development projects, as it does for the implementation of abstract energy policy targets into concrete site-specific solutions. We draw on the work of Adams \& Tiesdell (2013) that built up a taxonomy of planninginstrument types-shaping, regulatory, stimulus and capacity building - which cause different market impacts, and constitute of subsequent instrument sub-types, as briefly discussed in the following and applied on three cases in section 4 (see Table 4 for an overview).

Shaping instruments modify the behaviour of individual actors by changing institutional rules. These changes readjust the decision environment of market actors and encourage, manage or prevent real estate developments by plans, strategies or visions. Regulatory instruments are applied to compel, manage or dispel unwanted developments, limiting market actors' scope for autonomous action. Legal requirements or contractual arrangements are typically used to enforce regulatory intentions. Stimulus instruments increase the probability of desired events to happen due to being more rewarding for specific market actors by improving financial appraisals. Heurkens et al. (2015)0 state four instrument sets ranging from direct state actions - kick-starting developments - to price-adjusting, risk-reducing and capital-raising instruments that influence the attractiveness of locations, development types, or in our case energy efficiency measures more indirectly (e.g. tax-reduction, subsidies). The fourth instrument type is capacity building instruments that are applied to increase the efficiency of the three aforementioned instrument types, to facilitate their correct application by enhancing institutional and human capacities. Capacity buildinginstruments target market-cultures and ideas, knowledge, networks, and necessary capacities and skills. This requires mutual trust, respect and willingness to cooperate, eventually leading to increased public-private interactions and partnerships to achieve mutually beneficial outcomes (Heurkens et al., 2015; Castán Broto \& Bulkeley, 2013).

In the connotation of plan-shaped markets (and the public planner operating within the market and not standing at the side-line), we have to acknowledge that the instruments are applicable for both public and private planners. While the specific instruments may vary, the mechanisms remain the same. The application 
of planning instruments allows planners to realise urban development targets by influencing market actors' decisions (Adams \& Tiesdell, 2013). Proper planning instrument deployment will always lead to planning actions and subsequently market effects. In turn, planning instrument use will 'change the nature and effectiveness of other instruments' (Heurkens \& Hobma, 2014). This implies that planning instrument deployment is dependent on contextual factors. To analyse the application of planning instruments reasoned in complex public-private interactions, a basic understanding of the institutional context is helpful.

\subsection{Planning instrument choice and effects in relation to institu- tional development contexts}

Planning instrument choices and their effectiveness can be attributed to 'specific context-dependent institutional characteristics' (Squires \& Heurkens, 2016), as instruments are constructed and used in social relations between actors, reflecting their balance of power (Kassim \& Le Galès, 2010). Foremost the role and entanglement of the public in public-private interactions is varying across urban development contexts (Hodge \& Greve, 2010). Hence, in relation to the planshaped market concept we have to acknowledge the contextual setting of the development projects and energy policy targets as influential factors on planning instrument types. The context of real-estate developments can be conceptualised in various ways (Adams \& Tiesdell, 2013). However, conceptual models discussed in literature are not mutually exclusive (Squires \& Heurkens, 2016), as they are intersecting and the model-choice is dependent on the explanatory interest. The conceptual model introduced by Squires \& Heurkens (2016) enables an all-inclusive description of contextual factors in urban development projects influencing the planning instruments deployed to implement energy policies. In our aim to draw lessons on general findings on planning instrument deployment based on a cross-national case comparison, the awareness of interdependencies to timespace contexts of the cases is necessary (Rose, 1993).

The conceptual real estate development model depicts five institutional levels: the development environments, markets, agencies, processes and outcomes, which are interlinked by mechanisms such as institutional rules, market conditions, agency requirements and actions and evaluations (see Squires and Heurkens (2016) for further explanations). As the model is restricted to more general insights, it assists us in informing the explanation of differences in instrument choices beyond individual urban development projects and across national borders. The latter is of importance, as national politics and traditions are still seen as 'the most powerful factors in explaining various aspects of urban politics' (Pierre \& Peters, 2012).

\section{Methodology}

By analysing how climate mitigation policies are implemented in large urban development projects in the light of varying institutional and spatial settings, 
we want to generate meaningful insights (Miles, Huberman \& Saldana, 2014) on the planners' role and the instruments influencing market decisions to attain energy targets. This allows a broader understanding of how planners can shape local markets to enable innovative energy solutions and the contextual factors that have to be considered in this process.

\subsection{Analy tical framework}

The literature discussed in Section 2.3 and 2.4 jointly builds an analytical framework to analyse roles and actions of public and private actors involved in three urban development projects, eventually laying the foundation to explain how and why planners were able to implement energy policy targets. First (1), we examine the deployed planning instruments and related market effects based on (Adams \& Tiesdell, 2013), second (2), the institutional context of the urban development projects, as these influence the chosen planning instrument types (Squires \& Heurkens, 2016), and third (3), how these elements changed throughout the planning process (see Figure 1). The staging of the implementation process, as third element of our analytical framework, adds in combination with the first two elements (based on existing analytical models) a new perception to the literature, as we are able to assess the temporal development of how the handling of energy targets changed throughout the implementation process. This allows us to drawlessons on the effectiveness of instruments in relation to temporal and situative factors.

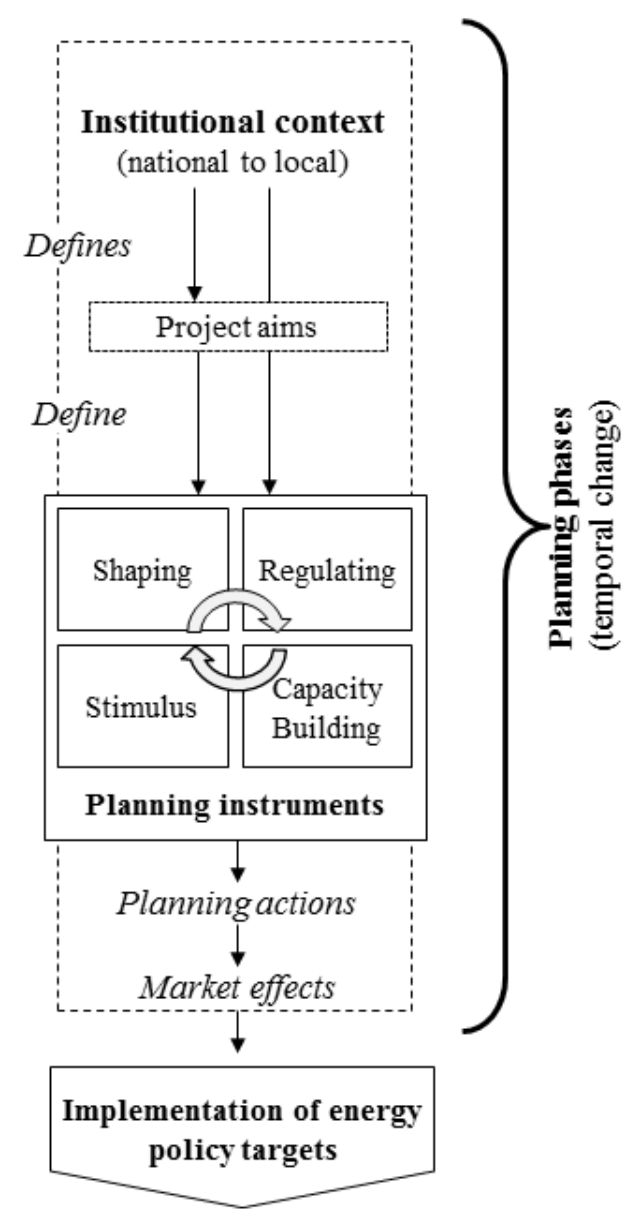

Figure 1: Framework to analyse implementation of energy policies in urban development projects (planning instruments, institutional context and temporal changes).

As we are aiming to identify a context-independent strategic pattern in the use of instruments at project level in different countries, it is crucial to understand the principal mechanisms in the relation of deployed planning instruments and implementation of energy policies at project level. For this purpose, an in-depth analysis of the institutional context for each case is not expedient. However, a comparative analysis of the institutional context offers us additional explanations why and how specific instruments were used, how the instruments were adapted to context-specific institutional rules or structures causing planning actions, to delineate case-specific from general findings. 


\subsection{Case selection}

We conducted a comparative analysis of three large-scale, urban development projects in the Netherlands, Germany and Denmark. An information-oriented case selection based on a deviant case strategy, according to Flyvberg (1993), has been applied. All three cases are recognised by practitioners and academics as innovative by means of a successful implementation of energy targets into the development. In accordance to Hobma (2011), we defined success multi-tiered: by quantitative metrics (e.g. achieved energy standard, GHG emissions), impacts on regional construction practices and the general embedding of energy targets, while achieving overall development targets. The three countries are internationally seen as role model for spatial planning. However, the national approaches to energy target implementation differ significantly and range from national government-driven, local government-driven and market-oriented policies.

\subsection{Data collection and analysis}

Data was collected in a four-tier approach: A review of existing literature-including related books, academic papers, and news articles-is the basis for each case. Supported by a content analysis of national legislation, policy documents, and partner agreements each implementation process was staged and the role of the national, urban, and local context assessed. Further impressions were collected through a mix of participant observation and site visits (Spradley, 1980). Based on these findings a total of seventeen semi-structured interviews were conducted from March to November 2017. Interviewees included representatives of the respective municipal authorities, municipal council or the respective public developers, private property development and residential construction companies, advising consultancy companies, energy utility companies or the supplier of pursuant technologies, and academic researchers associated with the urban development projects. The interviews took between 35 minutes and two hours, were audio-recorded, transcribed and pre-coded under sub-headlines in accordance to the research interest.

The data coding and analysis included inductive approaches, such as precoding, supplemented by deductive methods where categories from the literature and related themes in the analytical focus of the study were held against categories as identified by the inductive approach. Through this coding, we were able to recognise both case-specific factors and focal case features under consideration of the generalised planning instrument models from the literature. This enabled a deeper understanding of each case, followed by a cross-case comparison based on the analytical framework to draw lessons (Rose, 1993) on the implementation of energy targets in urban development projects.

\section{Case study analysis}

In this section, we analyse the main planning and development moments, the origin of the energy targets, and instruments used to secure their implementation in three urban development projects. Based on the framework from Section 3.1 the case findings are discussed in a cross-case comparison for lesson-drawing on the relevance of planning instruments for energy target implementation and their relation to institutional context. 


\subsection{Nordhavn, Copenhagen (DK)}

\subsubsection{Development background and implemented energy solution}

Nordhavn is a brownfield development in the former port facilities of Copenhagen, the capital of Denmark, and one of the largest Scandinavian urban development projects (see Table 1). The first development phase, comprising about $470,000 \mathrm{~m}^{2}$ gross floor area (200,000 $\mathrm{m}^{2}$ housing, 200,000 $\mathrm{m}^{2}$ commercial buildings, $70,000 \mathrm{~m}^{2}$ existing non-residential buildings), is to be completed in 2018 (see Figure $2 \& 3$ ). The area is owned and developed by Copenhagen City \& Port Development (CCPC), a publicly owned company (95\% of the shares held by Copenhagen municipality, 5\% by the state) (CCPC, 2009). Through a strong collaboration between CCPC, responsible for the operational project management, and the municipality that sets the framework conditions, market efficiency is combined with public legitimacy. Drivers for the development are the need for housing due to increasing population, and the financing of citywide infrastructure projects through land-sales (Katz \& Noring, 2007). Through a system approach at district scale, a flexible energy system integrates a prospective climate neutral low-temperature district-heating system with sustainability certified ${ }^{1}$ low-energy buildings, building-integrated energy supply and transportation infrastructures.

\subsubsection{Analysis of development process}

Up to five phases were identified (see Figure 4). The visioning phase defined general targets and the project framework, while energy targets derived from workshops and municipal ambitions were introduced in the long-term planning phase. The flexibility was already envisioned in the masterplan to brand Nordhavn as an internationally benchmark-setting sustainable district (CCPC, 2009) - in accordance with the municipal strategy of being climate neutral in 2025 and Copenhagen's efforts to position itself as leading 'eco-metropolis' since the 1990s (Blok \& Meilvang, 2014). Supporting contextual factors were the contemporaneous commitment of the national government to phase out fossil fuels until 2050 (Rasmussen, 2006) and the UNCOP-15 climate meeting in December 2009 in Copenhagen, where Nordhavn was presented as best-practice (CCPC, 2009).

${ }^{1}$ DGNB (Deutsche Gesellschaft für Nachhaltiges Bauen), a German sustainability scheme, adapted in Denmark in 2012 
Table 1: Nordhavn: Key figures

\begin{tabular}{|c|c|c|c|c|}
\hline $\begin{array}{l}\text { Timeframe } \\
\text { (first phase) }\end{array}$ & $\begin{array}{l}\text { Total size } \\
\text { (first phase) }\end{array}$ & Urban development project type & Energy innovation & Main stakeholders \\
\hline $\begin{array}{l}2005-2060 \\
(2005-2018)\end{array}$ & $\begin{array}{l}300 \text { ha } \\
\text { (20 ha) }\end{array}$ & $\begin{array}{l}\text { Mixed use development in a former har- } \\
\text { bour area (publicly owned), medium lot } \\
\text { sizes, housing for up to } 40,000 \text { people } \\
\text { and } 40,000 \text { jobs. Branded as sustainable } \\
\text { district, pedestrian and bike friendly, } \\
\text { mixed typologies, high real estate prices } \\
\text { ( } 25 \% \text { social housing) }\end{array}$ & $\begin{array}{l}\text { Energy system inte- } \\
\text { gration across sectors, } \\
\text { DGNB certified low- } \\
\text { energy buildings, cli- } \\
\text { mate neutral district- } \\
\text { heating }\end{array}$ & $\begin{array}{l}\text { Public development } \\
\text { company, municipality } \\
\text { public energy utilities, } \\
\text { various developers, } \\
\text { consultants and two } \\
\text { universities }\end{array}$ \\
\hline
\end{tabular}
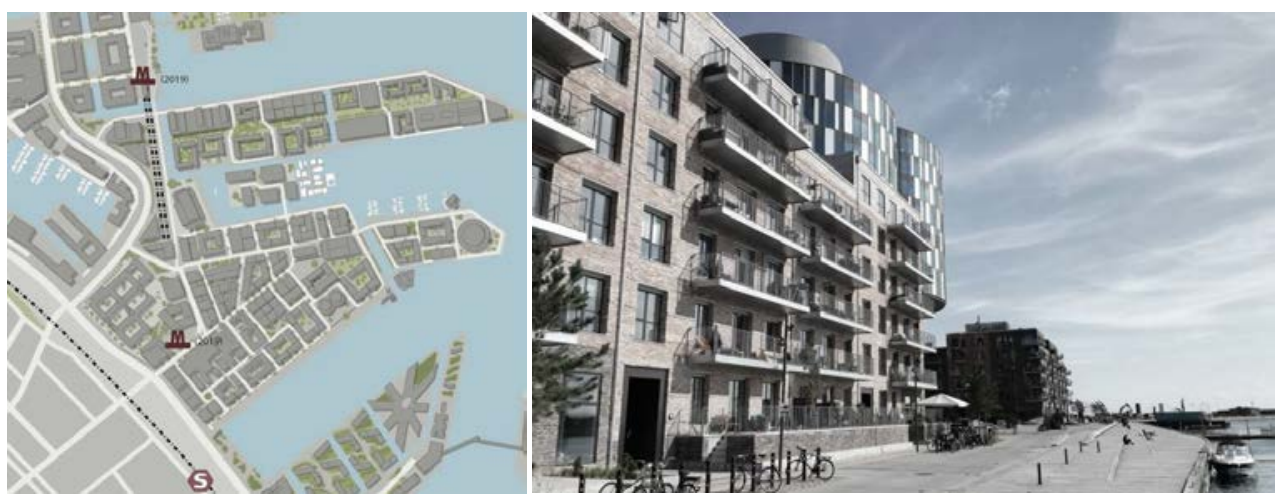

Figure 2: Map, first phase of Nordhavn (Source: (c) CCPC)

Figure 3: Waterfront Århusgade neighbourhood (Source: Authors)

The enactment of statutory plans initiated the implementation phase that set the framework for energy target implementation at individual sites, making use of the strong energy regulation instruments granted to Danish municipalities (Sperling, Hvelplund \& Mathiesen, 2011), such as designating Nordhavn as low energy housing area via the municipal plan. Supplementing, an energy partnership of the municipality, CCPC and various utilities was established in 2009 to develop integrated energy solutions. The partnership failed to deliver feasible solutions, as it was set up at management level focussing mainly on business cases with minor involvement of practitioners with the operational competencies (Hjøllund, Bøldt, Hendriksen \& Sieverts Nielsen, 2014). The non-achievement of several strategic targets for the Nordhavn development, due to the inadequately aligned deployment of planning instruments from public actors, led to a second longterm planning phase, in which planning instruments were readjusted.

A partnership agreement between municipality and CCPC led to the DGNB certification of the area and buildings (since 2016), tightened district-heating demands, the introduction of an early stakeholder dialogue, and the establishment of the EnergyLab Nordhavn project in 2015. The latter is a network of universities, utility and consultancy firms established by the municipality cooperating in a research and development project on energy system integration. Supported by state-funding, theimplementation of integrated urban energy solutions by experiment was achieved.

Throughout the development process, a constant shift between dominant governance levels can be observed. Initially the interaction happened mainly between national and city actors, which shifted in the long-term planning phase 
with the establishment of statutory plans and other instruments to an interaction between city and project level (CCPC). During the readjustment of planning instruments in 2014, a shift from merely project- site interaction to an entanglement of city-project-site interactions under inclusion of a wider stakeholder group occurred, leading to a more effective instrument deployment in the second implementation phase.

\subsubsection{Analysis of planning instruments and related market-decisions}

This section reflects on the role that planning instruments deployed by public authorities played to influence the decision environment and behaviour of market actors to implement energy targets.

Shaping instruments assisted in setting the main energy targets for the district. The consistent branding as a sustainable district, long-term and high ambitions in the masterplan, the thematic continuation in statuary and non-statuary plans, plus common action by the municipality and CCPC, created certainty and shaped the development conditions for the market to enable the high energy standards in Nordhavn.

In addition, the municipality made full use of their legal regulatory instruments. The obligatory connection to district-heating and the application of the Danish 2020 building code secured an energy baseline scenario above Danish standard through ridged requirements in statutory plans, which simultaneously set the boundary conditions for market investments. Also a required architectural approval by CCPC previous to the application for a building permission ascertained high quality building design beyond the scope of statutory plans. The necessity of a design proposal as prequalification demand in the tendering process and the quantitatively undefined DGNB certification, secured via the Local Development

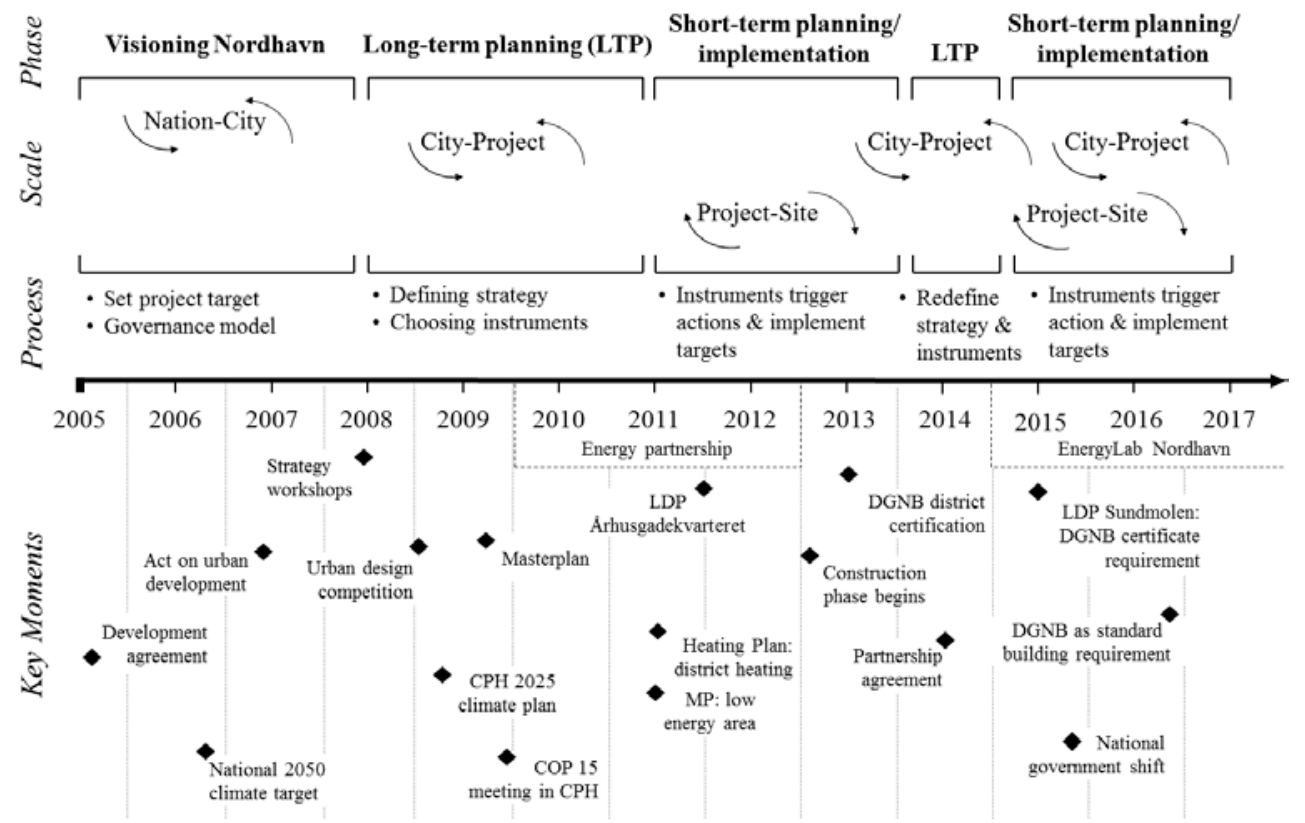

Figure 4: Sequencing of development, dominant scales \& implementation moments of energy targets in Nordhavn 
Plans (LDP) and sales contracts, stimulated private actors to come up with development concepts that integrated energy requirements ab initio.

Stimulus instruments influenced private investors' willingness to go beyond minimum energy standards. Infrastructure provision, co-funding of technical features and the DGNB area certification worked as a risk-reducing instrument, indicating long-term value stability for the pension fund-dominated Danish realestate market (Bovenberg, 2012). The DGNB building-certification was secured via regulatory instruments. The certification level was up to the developer, which stimulated investors to assess benefits and efforts of a certification.

The following public-private dialogue on sustainability issues, such as energy standards and the DGNB certification, built the capacity amongst key stakeholders to develop operational solutions at site-level that live up to the strategic targets of the masterplan. One concrete example was the EnergyLab Nordhavn project, which was introduced here to the private developers. The project itself is another capacity building instrument, since it integrated general municipal energy targets with site-specific investor targets-focussing on experimenting, an increase of knowledge, and mid-term benefits-by aligning interests and pairing market knowledge with technical competencies. This made the network a main enabler for the implementation of innovative energy solutions.

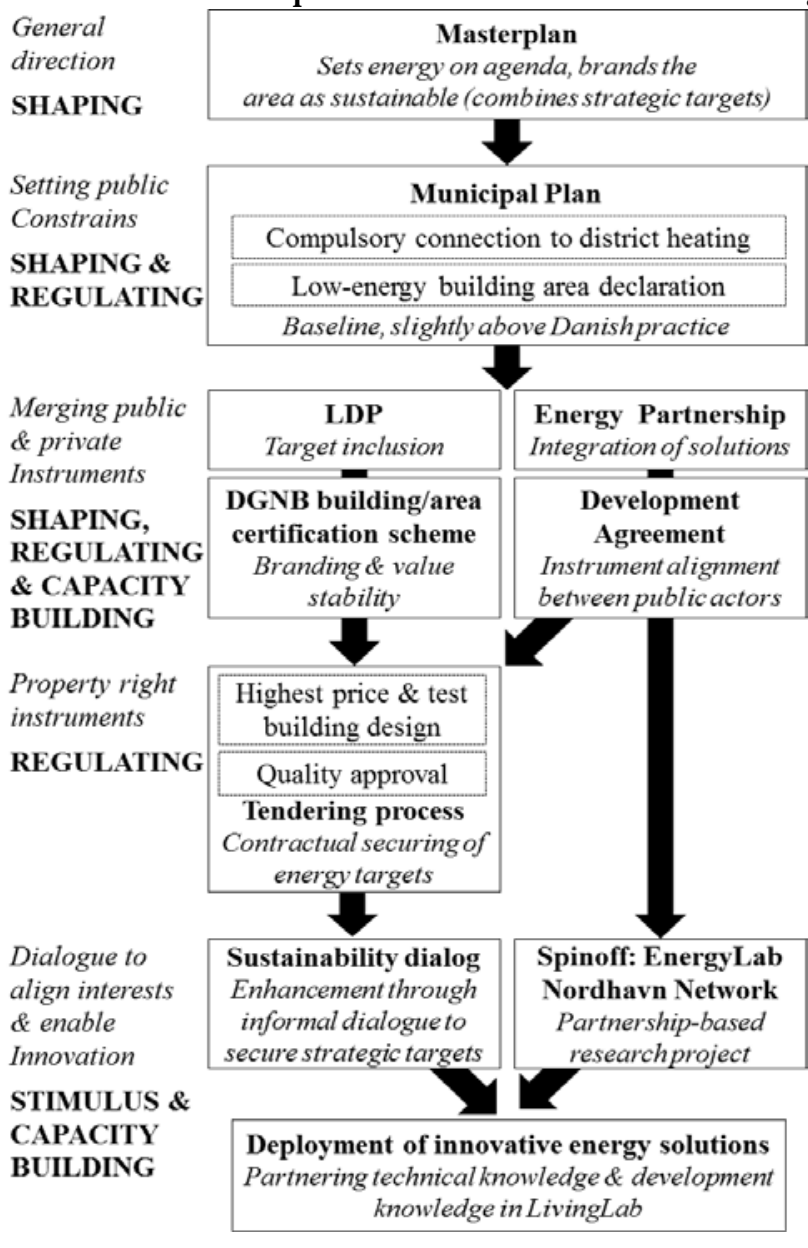

Figure 5: Staging of instrument deployment in Nordhavn to foster energy policy implementation
4.1.4 Sub-conclusion: Nordhavn

While shaping instruments provided the general direction for ambitious energy targets, the regulatory instruments secured a high energy standard baseline. The entanglement of public and private instrumentsfacilitated by the development agreement-enabled innovations beyond the reach of the individual public actors. Further, this set up the more dialogue-based instruments that stimulated the market and built capacity to innovate, leading to integrated energy systems.

The municipality actively used partnerships such as EnergyLab Nordhavn as strategic instruments, act- 
ing as facilitator in awareness of the market competencies required to reach their long-term targets. Knowledgeable actors committed to the project, as they were attracted in gaining knowledge about future technology solutions, possible business implications, contacts and profiling. Despite classifying EnergyLab Nordhavn as a learning project, developers used it as a branding and sales argument, since buyers in Nordhavn were considered more eco-conscious than the average.

The developers perceived the tight regulatory framework of sales contracts, statutory plans, and the required DGNB certification as challenging, but responded positively to the flexibility granted and the dialogue with the public authorities, which helped to diminish resistance against development requirements. The consequent use by CCPC and the coincident uptake of DGNB by Danish pension funds stimulated the market and led to a wider market acceptance of sustainability schemes as instrument to reach energy targets.

\subsection{Wilhelmsburg-Mitte, Hamburg (GER)}

\subsubsection{Development background and implemented energy solution}

Wilhelmsburg-Mitte is a brownfield development on a publicly owned former railway area in Hamburg. 330 apartments and 85,000 m2 office and service area were developed to shape a new community centre for the district of Wilhelmsburg. The development is embedded into an extensive urban renewal strategy for the district, a deprived area with 55,000 inhabitants on a river island belted in between highways, harbour uses, and industrial areas. Wilhelmsburg-Mitte was developed by the municipal-owned IBA Hamburg Corporation (IBA) through the facilitation of several PPPs.

In Wilhelmsburg-Mitte a low-carbon district heating network consisting of different, but interconnected decentralised building-integrated production units, was linked to buildings with high energy standards, advanced building energy concepts and material choices. Hence, 23 buildings form a virtual heating plant where the building-integrated production units can feed-in the excess heat in case of low internal demand into the distribution grid, which enables a more effective utilization of decentralised renewable energies. The energy network is designed for extension, since IBA is currently developing brownfield areas north of Wilhelmsburg-Mitte, with up to 4,500 new housing units (IBA Hamburg GmbH, Umweltbundesamt \&TU Darmstadt, 2015).

Table 2: Key figures of Wilhelmsburg-Mitte

\begin{tabular}{lllll}
\hline Timeframe & Total size & Urban development project type & Energy innovation & Main stakeholders \\
\hline $2007-2013$ & 20 ha & Mixed use development on former rail- & Integrated, open heat- & Public developer, mu- \\
& & way property in deprived area. Small - & ing network, linking & nicipality, public en- \\
& & medium lot sizes, 330 apartments, & low-energy buildings & ergy utility company, \\
& & 85,000 m² offices, service and other uses. with building-inte- & and private project \\
& Part of a building exhibition, connected tograted energy produc- & teams (developer-ar- \\
& new green area, multi-storey buildings, & tion & chitect-engineer) \\
& & & \\
\hline
\end{tabular}



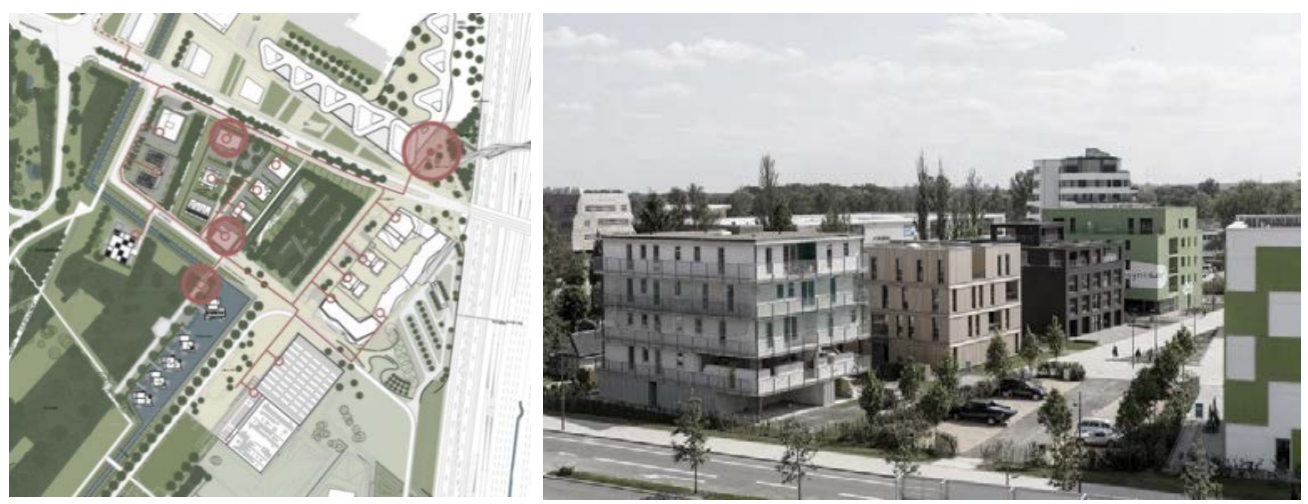

Figure 6: Masterplan of Wilhelmsburg Mitte including the district heating network (Source: (CIBA Hamburg $\mathrm{GmbH}$ )

Figure 7: 'Courtyard' in Wilhelmsburg Mitte (Source: () IBA Hamburg GmbH / Bernadette Grimmenstein)

\subsubsection{Analysis of development process}

Three planning phases were identified for Wilhelmsburg-Mitte (see Figure 8). In the visioning phase the urban renewal framework and targets were set, after local residents plead for improvements of living conditions in 2002 (IBA Hamburg $\mathrm{GmbH}, 2007 \mathrm{a}$ ), and a city growth strategy was enacted to position Hamburg internationally as metropolis (Altrock, 2004). The local government decided in 2005 to host a building exhibition ${ }^{2}$ in Wilhelmsburg that should solve both tasks (Klotz, 2014). Despite the provision of programmatic objectives by local citizens, a participatory interaction between city and district level happened first in the long-term planning phase with IBA as intermediate to translate the city growth strategy to project level. Here, project parameters for Wilhelmsburg-Mitte were defined by a masterplan in accordance to city targets, while the energy ambitions were set by IBA. As project developer and curator of the building exhibition, IBA set 'cites and climate change' (IBA Hamburg $\mathrm{GmbH}$ et al, 2015) as one of three key topics in reaction to the fourth IPCC assessment report (Bernstein, Bosch \& Canziani, 2008), since the district had been hit hard by storm surges in the past. In this context, the climate protection concept 'Renewable Wilhelmsburg' was developed by IBA, aiming for a 100 percent renewable energy supply of the district in 2050 (IBA Hamburg GmbH et al., 2015). Further, a consulting climate committee of national experts supported strategic decisions of IBA.

2 International Building Exhibition (Internationale Bauausstellung), a German urban development tool experimenting with new architecture and engineering concepts. 


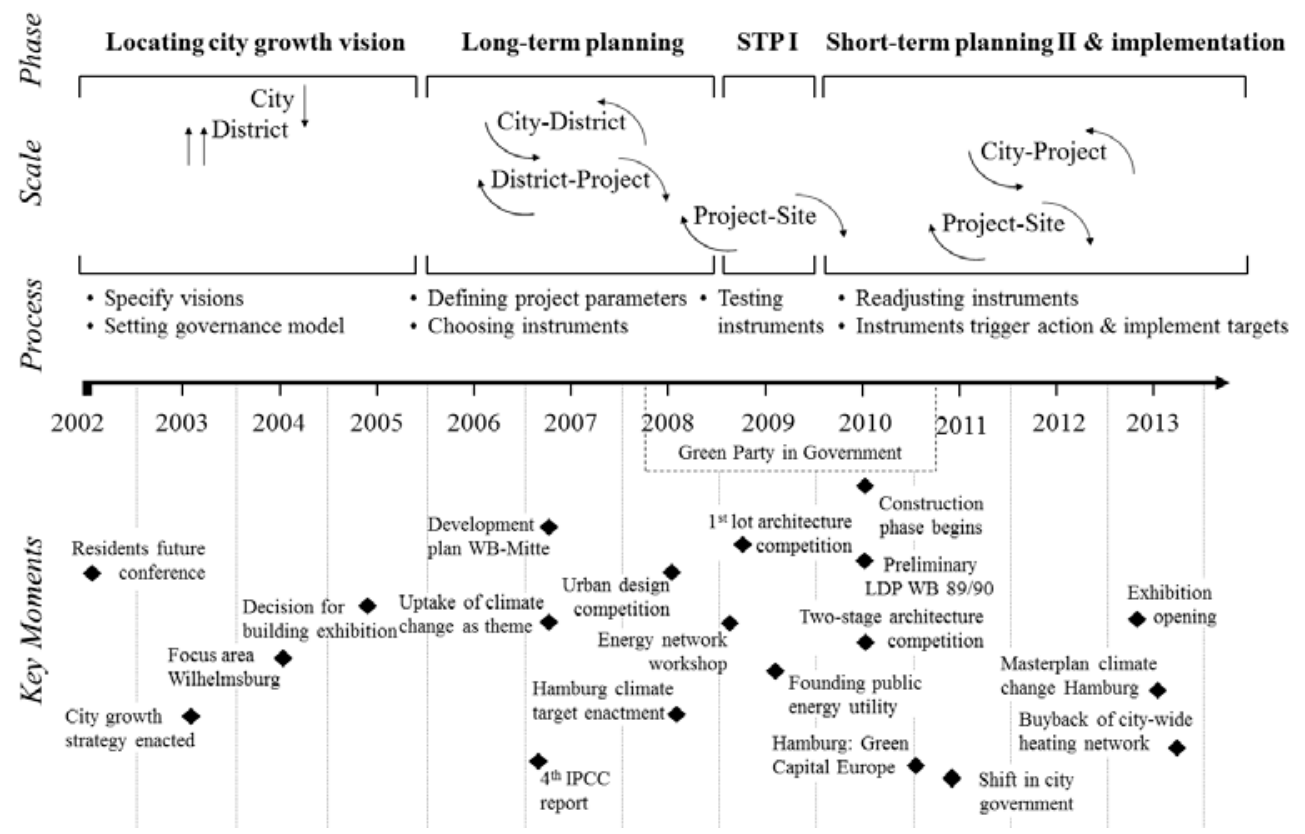

Figure 8: Phasing of development process, dominant scales \& implementation moments of energy targets in Wilhelmsburg

The implementation phase can be divided into two parts, since the first singlelot competition in 2009 was a trial for enabling building design innovation through regulatory requirements, which also included specific energy requirements stricter than the German building code (see Figure 9). The format was modified due to the challenged local real estate market for the remaining 22 plots in Wilhelmsburg-Mitte in a target-wise less restrictive two-stage competitive tender. First, interdisciplinary project teams could apply with an innovative building concept for a plot, which had to be refined together with an investor in the second step. Hence, the second implementation phase is characterised by the realignment of planninginstruments towards a more dialogue-based planning approach and the stronger inclusion actors at the city level. This is shown by the support of city politicians to encourage private investments in Wilhelmsburg-Mitte, or the direct award of the concession for the heating network operation to the re-established public energy utility company.

\subsubsection{Analysis of planning instruments and related market-decisions}

This section reflects on the role that planning instruments deployed by public authorities played to influence the decision environment and behaviour of market actors to implement energy targets.

Shaping instruments like the climate and energy consulting committee provided direction through branding the development as eco-friendly. These were in particular the uptake of 'cities and climate change' as key topic, followed by the development of the 'Renewable Wilhelmsburg' concept, and the emphasis on sustainability and high energy standards in the architecture competitions. The establishment of a building exhibition and the related public infrastructure investment plans (facilitated by Hamburg as a city-state, pooling exceptional funding 
tailored at the area) recalibrated the perception of the district and reshaped the local real-estate market, which proved to be vital parameters for a successful project development.

In regulatory terms, IBA used rigid energy standards in the competitive tender and contractual agreements in the land sales contracts as thresholds for the disbursement of innovation subsidies. A quality agreement defined the innovations that were subsidised by IBA, investors had to agree to specific 'criteria of excellence' committing to the innovativeness of the projects (IBA Hamburg $\mathrm{GmbH}$, 2007b), and they had to deposit a financial security guarantee. An external quality control advisor accompanied the construction phase to secure target implementation through timely recognition of aberrations from the contractual agreements.

Various stimulus instruments explicitly encouraged market actors with an 'ecoprofile' to contribute to the development project. As investors were either driven by ideology, reasons of prestige, or were looking for a testing ground of new building designs, Wilhelmsburg-Mitte provided an arena for all three investor types. The two-stage competitive tender stimulated the development of new building designs. Innovation funding, media attention of the building exhibition, directstate actions, and amenities in the land purchase balanced the challenging site and high energy demands, set by regulatory instruments, and worked risk-reducing and price-adjusting.

In addition, IBA built capacity for the development by setting up a network of partners from the public and private sector, and the climate committee, which supported investors and IBA through knowledge provision or project management expertise to realise the building designs and the heating network. Further, the required interdisciplinary collaboration in the tender merged relevant market knowledge with operational knowledge on building design. This continued in the refinement of building designs: the quality agreement and land sales contract were first concluded, as the final building form was developed. Investors perceived these negotiations as solution-oriented and collaborative, as IBA granted a leeway within the rigid regulatory framework and provided the necessary experts to realise the building designs by the use of its' network.

\subsubsection{Sub-conclusion: Wilhelmsburg-Mitte}

A well-aligned connection of instruments enabled the implementation of innovative energy technologies in Wilhelmsburg-Mitte. Stimulus instruments facilitated the emergence of innovative building designs developed in dialogue; capacity building instruments enabled the feasibility and adaption to market logic of the building designs and the energy network; and regulatory instruments kept up the innovation level to secure implementation and system integration. Shaping instruments only had indirect influence on the energy agenda, but were crucial for the whole urban development process by arousing market interest, which ensured that the other instrument types could be deployed effectively. 


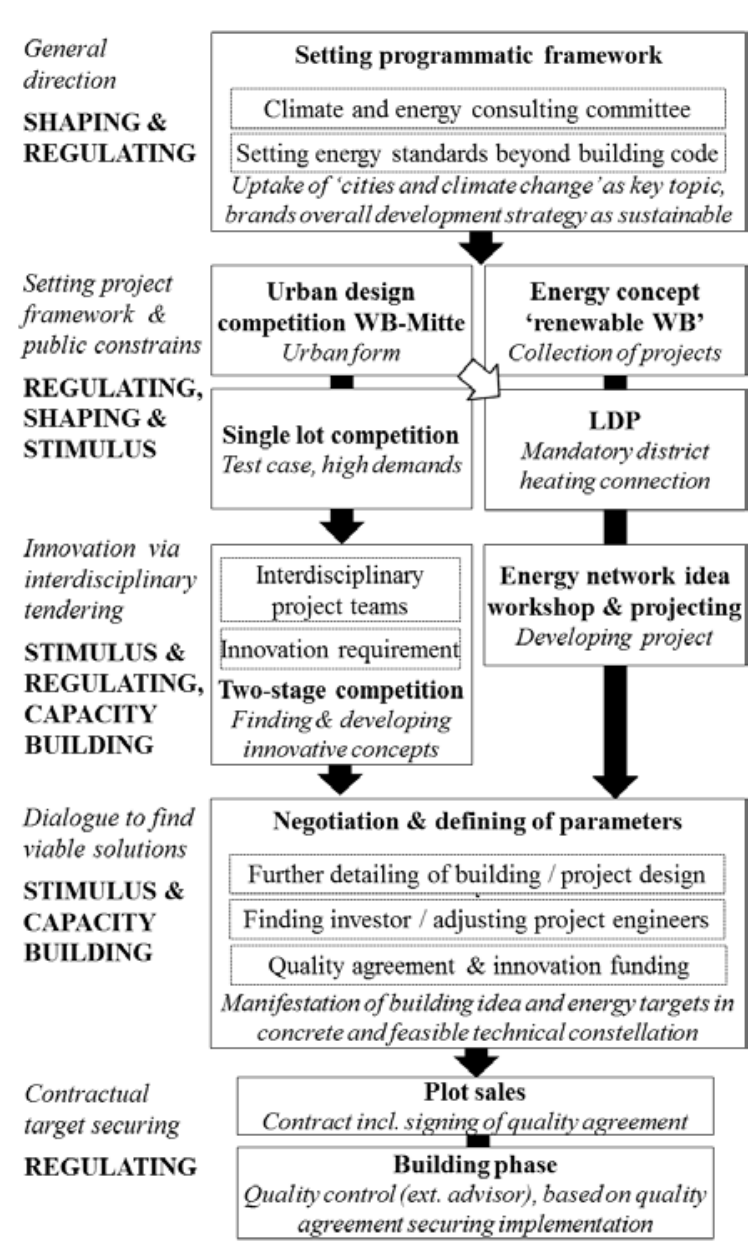

Figure 9: Staging of instrument deployment in Wilhelmsburg-Mitte for energy policy implementation
The general staging of instrument deployment was a deliberate strategy, initially developed in the long-term planning phase by IBA, in consultation with public and private experts. The strategy acknowledged the iterativeness of urban development projects and deliberately incorporated the emergence of specific instruments, as the readjustment of the used instruments after the trial competition in 2009 illustrated. Although IBA was the central actor, it acted mainly as facilitator and intermediate between city and private actors. Further, IBA functioned itself as market shaping instrument or 'urban laboratory' (Hellweg, 2008) and innovator, pushing the Hamburg administration energy policy, which led in 2013 to the enactment of a city-wide masterplan for climate protection (Scheffler, 2015).

\subsection{RijswijkBuiten, Rijswijk (NL)}

\subsubsection{Development background and implemented energy solution}

RijswijkBuiten is a brownfield development on a former glasshouse area in the municipality of Rijswijk. Up to 4,250 detached and row-house units plus 20 ha of commercial space will be developed until 2023 (by early 2017 1,000 houses were completed). Due to its vicinity to the big cities in the Randstad region the municipal population is constantly increasing. Since 2009 the area is developed by a separate program office within the municipal administration (PB) and the private development partner Dura Vermeer (DV). Rijswijk, as middle-sized municipality, acknowledged that they wouldn't be able to develop a project of this size solitary (Mensink \& Franzen, 2013) due to high interest costs from land acquisition, lacking market and sustainability knowledge. The commonly applied franchise or joint-venture models (J anssen-J ansen, Lloyd, Peel \& van der Krabben, 2013) were not applicable at the height of the financial crisis due to high financial liabilities, while the area had to be developed promptly to avoid further financial burdens. In 2011, the municipality issued a tender for a development 
Table 4: Key figures of RijswijkBuiten

\begin{tabular}{clll}
\hline $\begin{array}{c}\text { Timeframe Total } \\
\text { size }\end{array}$ & Urban development project type & Energy innovation & Main stakeholders \\
\hline $2006-2023230$ ha & $\begin{array}{l}\text { Mixed use area (focus on residential use) } \\
\text { on former greenhouse area (expropriated). }\end{array}$ & $\begin{array}{l}\text { Zero energy buildings to Municipality and pro- } \\
\text { low housing prices, sup- ject office, developer }\end{array}$ \\
& $\begin{array}{l}\text { Medium lot sizes, 4,250 apartments, 20ha } \\
\text { commercial use. Semi-detached and row- } \\
\text { houses, low-to-medium real estate prices, } \\
\text { closure of gap between two agglomerations }\end{array}$ & $\begin{array}{ll}\text { taic/ solar systems and } \\
\text { individual heat pumps }\end{array}$ & $\begin{array}{l}\text { consultants and sup- } \\
\text { plier of technical in- } \\
\text { stallations }\end{array}$ \\
\hline
\end{tabular}
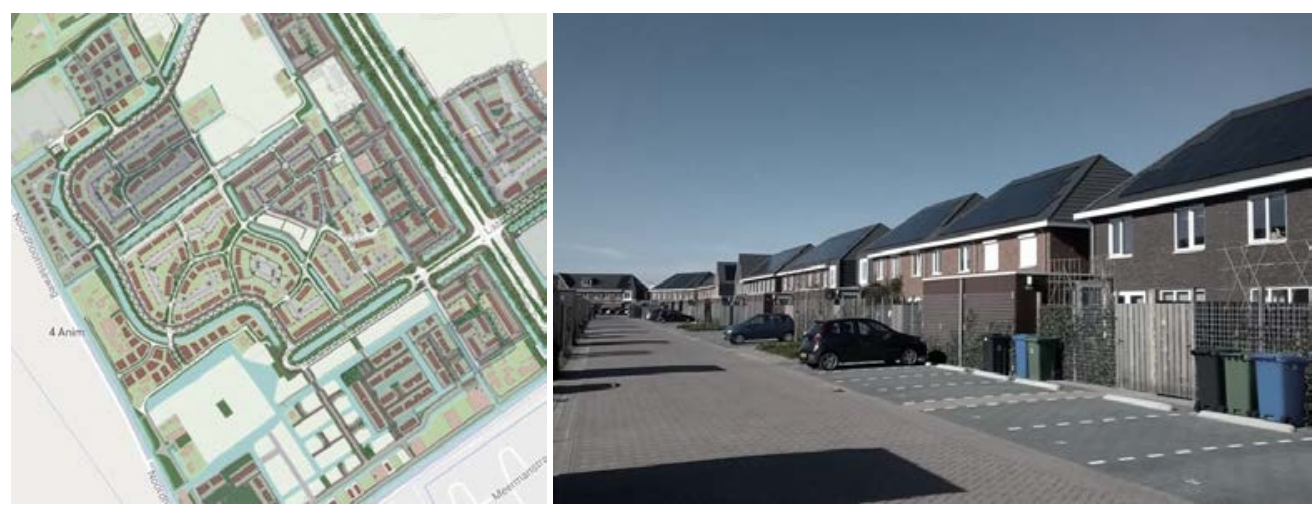

Figure 10: Excerpt of Masterplan for RijswijkBuiten, Sion neighbourhood (Source: (C) Gemeente Rijswijk)

Figure 11: Rowhouses in RijswijkBuiten, Sion neighbourhood (Source: Authors)

partner, in which DV acquired the exclusive building rights for a tranche of 250 houses.

This contractual partnership enabled the implementation of zero-energy buildings, supplied by individual solar power and heat pump systems. Instead of paying for the constructive measures and fuel consumption, the residents leased the energy technology. Thereby, an estimated ten percent cost-increase for the zeroenergy measures were relocated to the building operation phase and the residents, but replaced the normally occurring building operation costs due to de facto self-sufficiency. The technology is proven, but the dimension of the application - while maintaining low housing prices-is a notable example on how a sound financial model and a trust-based PPP enabled the realization of the local council's sustainability ambitions in an urban development project.

\subsubsection{Analysis of development process}

Three to four planning phases were identified for RijswijkBuiten (see Figure 12). After general discussions on the development of the area in the early 2000s, the land-purchase marks the transition from the visioning to the first long-term planning phase. The municipality proposed a low-density residential development of the area. The one-dimensional top-down approach led to a rejection of the LDP in 2008 by the region and neighbouring municipalities due to the vicinity to an industrial site, environmental issues and the general preference for a business-park in Rijswijk. This caused the shift to a more inclusive and participatory second long-term planning phase in the tradition of the Dutch corporatist 
policy making mode (Heurkens, 2012; Van Waarden, 2002) and marks the introduction of energy targets. Based on the premises of a 'sustainable development' (DeZeeuw, Franzen, Aalbers, Van Hal \&Dulski, 2010) and under involvement of various public and private stakeholders a masterplan was developed until 2009 (Gemeente Rijswijk, 2009).

The sustainability agenda-in concurrence with the financial crisis as window of opportunity - was a form of capacity building for the development process. Driven by the PB and the municipal council, zero-energy buildings were seen as a unique marketing feature. Due to lacking regulatory instruments to enforce higher standards, the tender for a development partner was constructed in a way that ensured a private bidder offering zero-energy solutions. Earlier workshops highlighted the need for a collective electricity network, whereas heating should be organised individually, which was backed up by a feasibility analysis of the energy concept (De Zeeuw et al., 2010). Consequently, low energy buildings and individual heating solutions were included in the masterplan (Gemeente Rijswijk, 2014), and the LDP was the first in the Netherlands that set a minimum value of a Dutch sustainability certification scheme ('Duurzaamheids Profiel van een Locatie') as development aim (De Zeeuw et al., 2010).

The two long-term planning phases were a quest for the right methods to enable the abstract vision of a residential development. With the inclusion of DV as development partner the implementation phase begun. The overall framework (spatial program and project governance structure) was set, but the site-specific spatial and technical configurations still had to be developed, offering some development and design flexibility, which proved to be vital for the progress of the project.

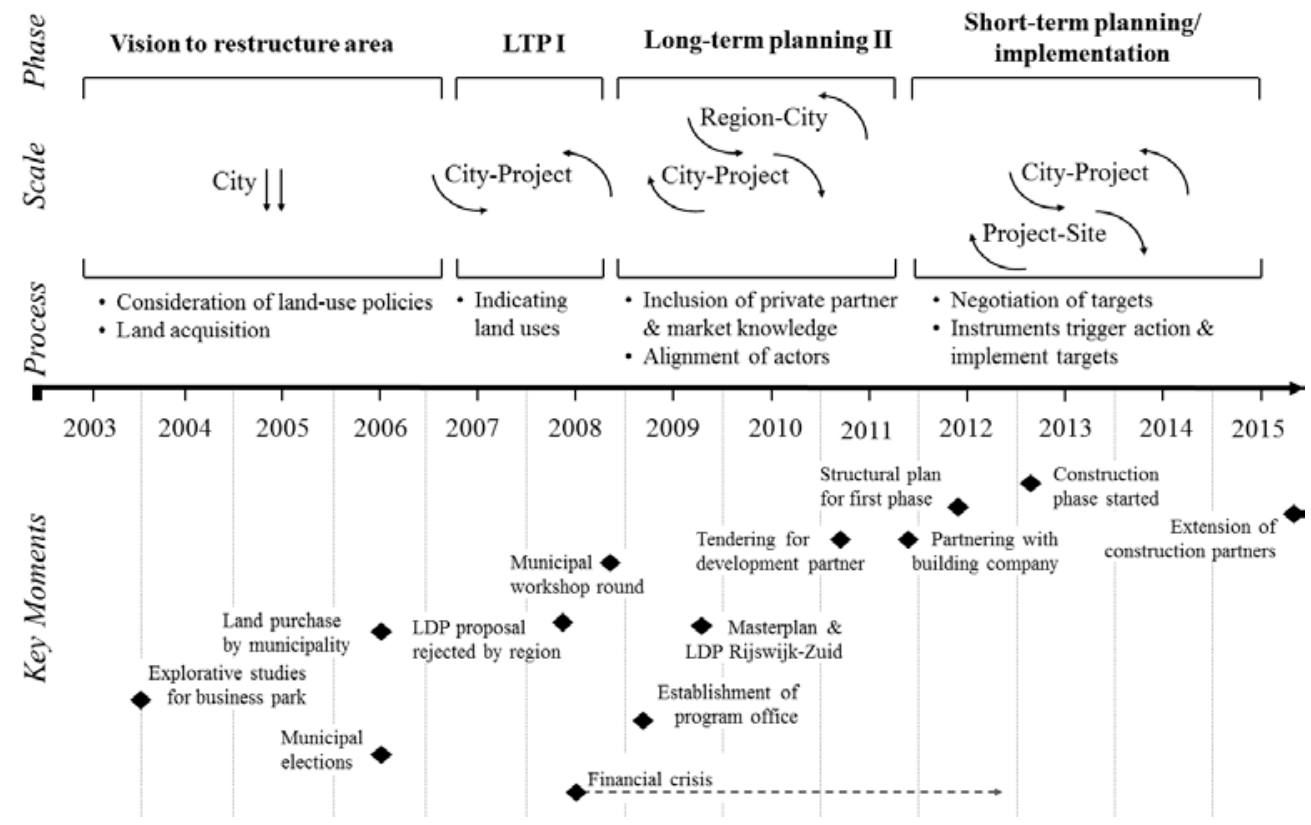

Figure 12: Phasing of development process, dominant scales and implementation moments of energy targets in Rijswijk 


\subsubsection{Analysis of planning instruments and related market-decisions}

This section reflects on the role that planning instruments deployed by public authorities played to influence the decision environment and behaviour of market actors to implement energy targets.

Shaping instruments influenced the energy target implementation indirectly. The definition of a conceptual framework in the masterplan offered flexibility for emerging developments, while the sustainability certification in the LDP worked as self-assessment, and communicated the sincerity of the municipal ambitions to private investors and the formerly objecting regional authority and neighbouring municipalities.

Due to the real estate market situation, the municipality's size, and the chosen PPP-model, regulativeinstruments played a minor role as the municipal sustainability ambitions could not be enforced upon market actors. Instead the regulative instruments supported shaping and stimulus instruments to secure a minimum standard and to brand the area as sustainable. This is exemplified by the contractual grant of exclusive building permission rights to DV that contained a withdrawal clause; hence, the clause worked more risk-reducing than as regulating for the developer.

A very decisive role played by the $\mathrm{PB}$ in stimulating market actors to come up with concrete technical solutions to meet the energy targets was to reduce financial risks with a sound financial model. While the land development risks re-

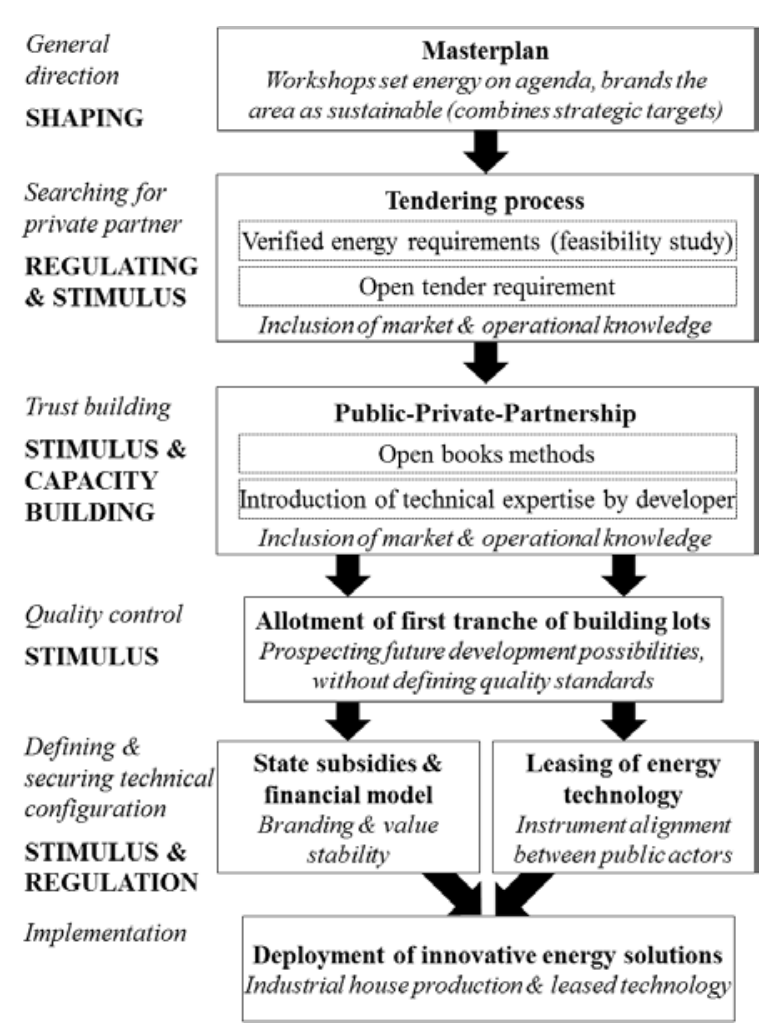

Figure 13: Staging of instrument deployment in RijswijkBuiten for energy policy implementation mained with the municipality, DV bore the building-related risks (the building energy system operation was managed by a subcontractor liable to DV). The strategic partnership without legal entity enabled the commitment of DV, as the initial risk for DV was reasonable. Further, DV was stimulated to optimise their building design towards zero-energy to win the tender. The option of a second tranche of 250 houses-based on the (objectively not measurable) condition that the municipality was 'satisfied'-stimulated DV to find innovative solutions to realise zero-energy buildings with a restricted budget, as this meant a constant income to maintain staff during the market low. 
Building capacity to develop RijswijkBuiten was a main achievement of the PPP. DV contributed with real estate market and sustainability knowledge, while connecting the municipal network of advisors and consultants with its own network of subcontractors, such as the technology supplier. The latter eventually came up with the technology leasing model as deliverer of the technical means to achieve the municipal energy targets. The work with one development calculation resulted in alignment of municipal policy with market process logic, shaping an informal interaction arena of mutual understanding, trust and knowledge sharing. The horizontal organizational relationships and the flexibility allowed the influx of new ideas for the short-term planning within the framework shaped by the masterplan.

\subsubsection{Sub-conclusion: RijswijkBuiten}

While shaping and stimulus instruments were dominant for the overall development, stimulus and capacity building instruments were formative for the implementation of municipal energy targets. Municipal ambitions and the stimulated creativity in public-private interaction enabled an open discussion on how to achieve the energy targets, and not how to implement a specific technology. This technology-open process allowed theidentification of a feasible techno-economic constellation achievable by involved market participants.

The success of the approach is illustrated by two aspects. First, the introduction of energy targets at project-level and the successful 'eco-district experiences' (Fitzgerald \& Lenhart, 2016) accelerated the municipality's climate planning, leading to an enactment of a first coherent climate change policy in 2016 (Gemeente Rijswijk, 2016). Second, all private developers in RijswijkBuiten adopted the zero-energy building standard and the leasing-model. According to the PB, none of them questioned the municipal demands, due to the sound business case at hand. This shows that the PB was able to shape a local market to implement energy solutions beyond formal governance instruments, without straining the social or financial project aims.

\subsection{Cross-case comparison}

Comparing the cases with recourse to the framework from Section 3 provides insight into the empirical use of planning instruments as means to implement energy targets into urban development projects. Table 4 provides an overview of the variety of the shaping, regulatory, stimulus and capacity building instruments used by the planning authorities in Nordhavn, Wilhelmsburg-Mitte and RijswijkBuiten, which influenced the implementation of energy policy targets.

In all cases, the energy targets were first introduced throughout the long-term planning phase, after social or economic project targets were set. Subsequently, shaping instruments were deployed first to frame energy targets, supported by regulatory instruments to secure high baseline standards. This generated awareness and set a coherent framework for energy target implementation to prepare the efficient deployment of stimulus and capacity-building instruments in the short-term planning phase. 
Table 4: Planning instruments used in Nordhavn, Wilhelmsburg-Mitte and RijswijkBuiten to enable the delivery of innovative energy technologies manifesting energy policy targets

\begin{tabular}{|c|c|c|c|}
\hline \multicolumn{2}{|c|}{ Instruments Nordhavn } & $\begin{array}{l}\text { Wilhelmsburg-Mitte } \\
\begin{array}{c}\text { Development/investment plans } \\
\text { Infrastructure relocation plan }\end{array}\end{array}$ & $\begin{array}{l}\text { RijswijkBuiten } \\
\begin{array}{c}\text { Development/investment plans } \\
\text { n/a }\end{array}\end{array}$ \\
\hline Shaping & $\begin{array}{l}\text { Development/ investment plans } \\
\text { Public transport extension } \\
\text { Regulatory plans } \\
\text { LDP (district heating constraint, } \\
\text { DGNB certification) } \\
\text { Municipal plan (low energy area) } \\
\text { Indicative plans } \\
\text { Masterplan }\end{array}$ & $\begin{array}{l}\text { Development/investment plans } \\
\text { Infrastructure relocation plan } \\
\text { Regulatory plans } \\
\text { LDP (district heating constraint) } \\
\text { Indicative plans } \\
\text { Programmatic framework Mitte } \\
\text { District energy concept } \\
\text { City growth strategy }\end{array}$ & $\begin{array}{l}\text { Development/investment plans } \\
\text { n/a } \\
\text { Regulatory plans } \\
\text { LDP (sustainability tool) } \\
\text { Indicative plans } \\
\quad \text { Masterplan } \\
\quad \text { Energy concept }\end{array}$ \\
\hline Regulatory & $\begin{array}{l}\text { State/ third party regulation } \\
\text { DGNB building certificate } \\
\text { Low-energy standard } \\
\text { Contractual regulation } \\
\text { Tender requirements } \\
\text { District heating connection }\end{array}$ & $\begin{array}{l}\text { Contractual regulation } \\
\text { Quality agreement (district } \\
\text { heating, energy standards,...) }\end{array}$ & $\begin{array}{l}\text { State/ third party regulation } \\
\text { Development permit } \\
\text { Contractual regulation } \\
\text { Low-energy buildings (zero-energy } \\
\text { building ready) }\end{array}$ \\
\hline Stimulus & $\begin{array}{l}\text { Direct state actions } \\
\text { Infrastructure provision (traffic) } \\
\text { Price-adjusting actions } \\
\text { Technical feature co-funding } \\
\text { Risk-reducing actions } \\
\text { DGNB area certification } \\
\text { Development agreement } \\
\text { Capital-raising actions } \\
\text { J oint-ventures for key buildings }\end{array}$ & $\begin{array}{l}\text { Direct state actions } \\
\text { Infrastructure relocation } \\
\text { New public buildings } \\
\text { Price-adjusting actions } \\
\text { Innovation funding } \\
\text { Governmental subsidy } \\
\text { Risk-reducing actions } \\
\text { Political backup } \\
\text { Capital-raising actions } \\
\text { Investor inclusion in architectural } \\
\text { competition and before tender }\end{array}$ & $\begin{array}{l}\text { Direct state actions } \\
\text { Land-banking } \\
\text { Price-adjusting actions } \\
\text { Governmental subsidy } \\
\text { Risk-reducing actions } \\
\text { Withdrawal clause } \\
\text { Financial model (risk sharing) } \\
\text { Transparency in cooperation } \\
\text { Capital-raising actions } \\
\text { Financial model (interest rate) } \\
\text { Self-subsidy from land-exploitation }\end{array}$ \\
\hline
\end{tabular}

In specific, what can be learnt from all cases is that for favourable market decisions to integrate energy targets in urban projects, a conscious combination of planning instruments should be deployed to balances financial risks and certainty with development flexibility and market opportunity. For instance, stringent energy demands were balanced by stimulus instruments resulting in riskreduction, and providing special development conditions, which engaged private market actors in the development projects. Moreover, PPPs established informal knowledge exchange arenas in the soft space between statutory government spaces (Haughton, Allmendinger \& Oosterlynck, 2013), enabling an equal interaction between private deliverers and framework-setting public planners. The resulting open discussions extended the decision room of individual actors and built the necessary capacity to develop site-specific technical configurations that 


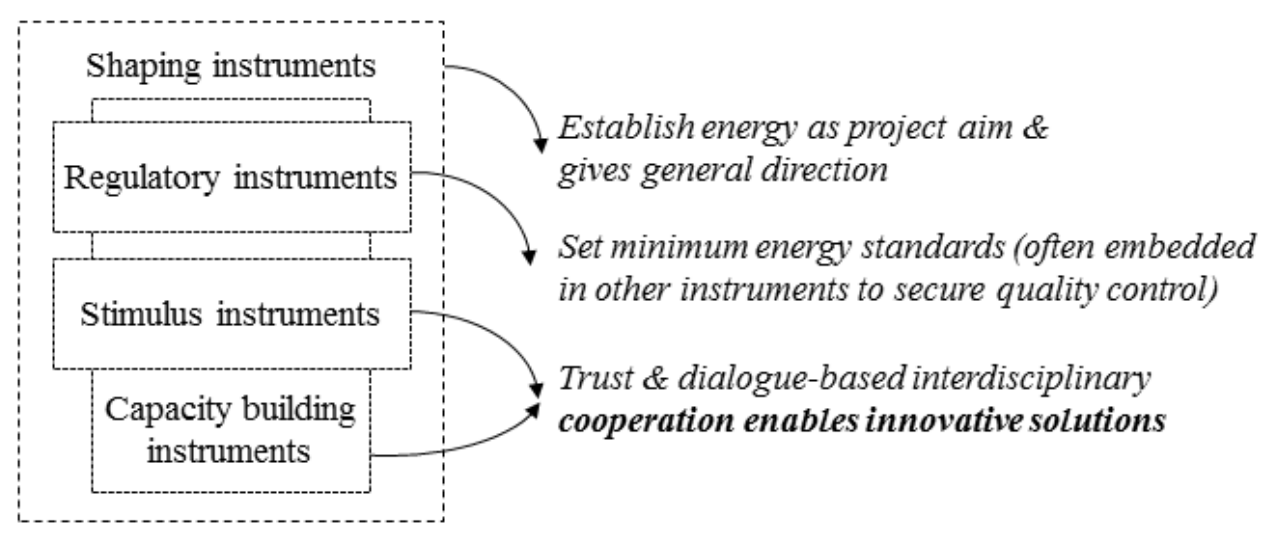

Figure 14: Synopsis of market effects caused by instrument deployment enabling the implementation of energy targets through innovative energy technologies

comply with the overall energy targets. Also, this implicates the importance of the tendering process for the implementation of energy policies.

Figure 14 illustrates a pattern of deployed instrument types and resulting market effects. The cases showed that a successful implementation of energy policies in urban development projects is supported by an initial deployment of shaping and regulatory instruments helping to establish a hard long-term framework. This prepares the effective use of stimulus and capacity building instruments that enable an interdisciplinary dialogue about site-specific energy solutions. An important lesson is that energy policies set by shaping and regulatory instruments should be set early, but to some extent remain technology-open, as the specific technical constellations are first developed, defined and agreed at site-level.

The inclusion of private market actors' interests in plan- and decision-making on energy targets in urban development projects indicates the planners' awareness of their market shaping role, as only long-term planning involving higher administrative levels remained a public task, while private actors financed and delivered the energy solutions. This shows the necessity to include private market actors and their competencies to achieve energy targets.

Further, all four planning instrument types are of crucial importance for the implementation of energy policies, as their strong entanglement and mutual enhancement of the individual instrument market effects through planning actions illustrates. While stimulus and mostly capacity building instruments enable the actual dialogue to develop innovative site-specific energy solutions, the framework in which these negotiations happen is set by shaping and regulating instruments, as these define targets, raise awareness and set minimum standards as benchmark. Additionally, these dialogues should be technology-open, aiming for the overall ambitions of the masterplan and not specifically regulated technical constellations, as earlier considerations might be unfeasible due to changes in the institutional context, such as changing real estate demand.

Additionally, the alignment of governmental levels in later project phases for a more effective instrument deployment bridging 'governance gaps' (Pierre \& Peters, 2012) illustrates the iterativeness of development processes, leading to unique governance setups and individual instrument choices for each case 
(Pressman \&Wildavsky, 1973). The significant differences in instrument deployment and technical solutions across cases can be explained by country or cityspecific institutional settings. The cooperative planning approach in Denmark (Oteman, Wiering \& Helderman, 2014), strong regulatory frameworks in German planning policies (Waterhout, Othengrafen \& Sykes, 2013), or the decentralised governance approach in the Netherlands (van der Krabben \& Heurkens, 2015) can be recognised within the cases as safeguarding mechanisms for energy target achievement, primarily approached via capacity building in Nordhavn, regulatory instruments in Wilhelmsburg-Mitte, or stimulus instruments in RijswijkBuiten.

Due to longer tradition in local energy planning (Oteman et al, 2014), municipal energy planning is more institutionalised in Germany and Denmark, which has led to a firmer entanglement of shaping and regulating instruments than in the Netherlands. This institutionalisation is one explanatory factor for theemergence of energy targets from different governmental levels across cases; ranging from city-induced energy targets in Nordhavn to project-originated targets accelerating the municipal energy policy as in Wilhelmsburg-Mitte and RijswijkBuiten. Further, the case of the PPP in Rijswijk - shaped by regional traditions (Hendriks, 2006), financial pressure and the aim to realise high energy standards-shows that a deliberate alteration of project governance structures can be a viable way to increase the efficiency of planning instruments.

This indicates that for each project in a particular institutional setting, such as regulatory systems, real estate markets or dominant governance modes, different supporting factors assisting the effectiveness of planning instruments to implement energy targets can be found. These are in particular local governance structures, existing energy policies, sustainability-related events such as the COP 15 meeting in Copenhagen, real estate market conditions such as the financial crisis in RijswijkBuiten causing the uptake of energy standards as means to initiate the development, or political support such as in Wilhelmsburg-Mitte. However, due to their context dependency, these factors are not reproducible and might not be supportive in other contexts.

\section{Conclusion}

This paper has provided insight into how public authorities implemented energy policies in three urban development projects in north-western Europe through the deliberate deployment of planning instruments that shape, regulate, stimulate and build capacity for development decisions from private market actors.

The cross-case comparison revealed that planners already have a wide selection of instruments, provided that they are able to align the different actors and exploit their competencies. In this way planners can support the implementation of energy policies through the iterate use of various planning instruments to mobilise public and private stakeholders in urban development projects towards the energy targets. Planners play a crucial role by developing well-informed planning strategies that integrate energy policy targets with market interests. 
Through a mix of shaping and regulatory instruments, energy targets can be integrated early in the long-term planning framework of urban development projects securing a minimum standard. On top of this, stimulus instruments can incentivise market actors to comply with the targets, whereas capacity building instruments provide the platform to align development aims with market decisions. Tender processes provide an arena that eventually enables the identification of viable technological solutions in accordance to overall energy targets, since previously deployed instruments take full effect here when market logics are merged with public legitimacy at site-level. This illustrates the iterativeness of implementation processes, but also how the strategic and directed deployment of planning instruments can extend the market actors decision room in negotiations at sitelevel to translate energy policies into viable reconfigurations of the built environment.

The resulting interaction between public and private actors enables thenecessary creativity, trust and complementary capacity increase to develop site-specific solutions in technology-open processes thereby translating abstract energy policies into operational configurations in the built environment. This demonstrates the dependency on private market actors to implement energy policies, while private actors are mutually dependent on the public to effectuate investment strategies. The implementation of energy policies in urban development projects can succeed if public and private interests are aligned by a well-attuned deployment of available planning instruments from various governmental levels, as the particular instrument combinations in all three cases have illustrated.

Despite a similar available instrument mix across cases, the context-dependent institutional characteristics of each development project induce a tailor-made choice for adequate instruments to shape markets for the implementation of energy policies. In turn, this entails that planners can find supportive factors for energy policy implementation in their specific institutional setting, causing unique implementation pathways. However, to recognise these non-replicable factors, extensive knowledge of strategy, planning instruments and a sense of occasion are required to stage the implementation process and exploit the momentum of emergent developments. Thus, the application of the concept of 'planshaped markets' (Adams \& Tiesdell, 2010) makes a novel contribution to the energy planning and climate governance literature by a more action-related approach, focussed on the planner, how energy targets are negotiated between public and private actors and implemented in daily practice.

Limitations might arise from the selection of frontrunner cases with similarstructured planning entities, while there might be valuable learnings in cases of unsuccessful instrument deployment. In acknowledging that, we stress that this study identifies patterns in the use of planning instruments to implement energy policies that are context-independent and thus reproducible, which provides important lessons for practitioners in other national contexts.

Although having identified supporting and contradictory factors for efficient instrument deployment within the institutional contexts of the cases, our findings are limited in terms of generating deeper insights on the role of institutional con- 
texts in relation to available planning instruments and their market effects. Despite profound case investigations, our analytical framework might simplify institutional relationships, agency behaviours or personal competencies and national path dependencies, as there are inevitably multiple reasons that cause success of urban development projects. However, within the scope of this cross-national case comparison-focussing on the identification of commonalities in instrument use and underlying mechanisms-it has been impossible to comprehend all reasons that have determined the successful implementation of energy targets. A participatory research approach for individual cases could have been a methodological solution. Nevertheless, the cases reveal that that the merging of competencies in formalised and informal public-private partnerships and the resulting open discussions throughout the tender processes have been important in achieving energy targets within urban development projects.

Therefore, we recommend further research on the relation between instruments and the institutional context in individual case studies to provide insights for a deeper understanding of the situativeness of instrument choice and effects. To increase the significance of the arguments made in this paper, the inclusion of other planning-entity setups-for instance within formal governance structures or in purely private property development projects-might be worth exploring.

\section{Acknowledgments}

We thank all interviewees related to the three cases who provided insight and expertise that greatly assisted the research, even though they might not agree on

all aspects of our conclusion. Further, we thank the anonymous reviewers for their valuable comments and suggestions to improve the quality of the paper.

\section{References}

Adams, D., Tiesdell, S. (2010). Planners as Market Actors: Rethinking StateMarket Relations in Land and Property. In Planning Theory \& Practice 11 (2), 187- 207.

Adams, D., Tiesdell, S. (2013). Shaping places. Urban planning, design and development. London, New York, USA: Routledge, 286-294.

Altrock, U. (2004). Das Leitbild von der „Wachsenden Stadt“ — genial oder fatal? In Uwe Altrock, Dirk Schubert (Eds.). Wachsende Stadt. Wiesbaden, Germany: VS Verlag für Sozialwissenschaften, 77- 94.

Bernstein, L., Bosch, P., Canziani, O. (2008). Climate Change 2007. Synthesis Report: An Assessment of the Intergovernmental Panel on Climate Change. Geneva, Switzerland: Intergovernmental Panel on Climate Change.

Blok, A., Meilvang, M. (2014). Picturing Urban Green Attachments: Civic Activists Moving between Familiar and Public Engagements in the City. In Sociology 49 (1), $19-37$.

Bovenberg, L. (2012). Benchmarking the Danish pension system: a comparison with Dutch pensions. In Nationaløkonomisk Tidsskrift (150), 228- 233.

Bryson, J . (2011). The Strategy Change Cycle: An Effective Strategic Planning Approach for Public and Nonprofit Organizations. In J ohn M. Bryson (Ed.). 
Strategic planning for public and nonprofit organizations. A guide to strengthening and sustaining organizational achievement. 4th Edition. San Francisco USA: J ossey-Bass, pp. 41- 80.

Bulkeley, H., Betsill, M. (2005). Rethinking Sustainable Cities: Multilevel Governance and the 'Urban' Politics of Climate Change. In Environmental Politics 14 (1), 42-63.

Bulkeley, H., Moser, S. (2007). Responding to Climate Change: Governance and Social Action beyond Kyoto. In Global Environmental Politics 7 (2), 1- 10.

Callon, M. (1986). The sociology of an actor-network. In M. Callon, J . Law, \&A. Rip, eds. Mapping the Dynamics of Science and Technology. London, UK: Macmillan, pp. 19- 34.

Castán Broto, V., Bulkeley, H. (2013). A survey of urban climate change experiments in 100 cities. In Global environmental change: human and policy dimensions 23 (1), 92- 102.

Connors, P., McDonald, P. (2011). Transitioning communities: community, participation and the Transition Town movement. In Community Development J ournal 46 (4), 558- 572.

CPH City and Port Development (CCPC) (2009). Nordhavn Urban Strategy. Available online at http:// www.nordhavnen.dk/ / media/_newnordhavnen/nordhavnen_strategy_271009.pdf?la=da-dk.

Daamen, T. (2010). Strategy as force. Towards effective strategies for urban development projects: The Case of Rotterdam CityPorts. Amsterdam, Netherlands: IOS.

De Zeeuw, F., Franzen, A., Aalbers, K., van Hal, A., Dulski, B. (2010). Designing the Future. In Sustainability 2 (4), 902-918.

Fitzgerald, J ., Lenhart, J . (2016). Eco-districts: can they accelerate urban climate planning? In Environ Plann C Gov Policy 34 (2), 364- 380.

Flyvbjerg, B. (1993). Rationalitet og magt. Et case-baseret studie af planlægning, politik og modernitet. 4. oplag. København, DK: Akademisk Forlag.

Gemeente Rijswijk (2009). Masterplan Rijswijk-Zuid. Rijswijk: 11/03/ 2009.

Gemeente Rijswijk (2014). Bestemmingsplan "Sion - 't Haantje, tweede herziening". Rijswijk: 09/30/2014.

Gemeente Rijswijk (2016). Meerjarenactieplan 2016-2018 bestuurlijke opgave duurzaamheid. Rijswijk: 08/2016.

Guy, S., Shove, E. (2000). A sociology of energy, buildings, and the environment. Constructing knowledge, designing practice (Roudedge Research Global Environmental Change Series, 5).

Harman, B., Taylor, B., Lane, M. (2015). Urban partnerships and climate adaptation: challenges and opportunities. In Current Opinion in Environmental Sustainability 12, 74- 79.

Haughton, G., Allmendinger, P., Oosterlynck, S. (2013). Spaces of neoliberal experimentation: soft spaces, postpolitics, and neoliberal governmentality. Environment and Planning A 45, 217- 234.

Healey, P. \& Hillier, J . (2008). Political Economy, Diversity and Pragmatism: Critical Essays in Planning Theory -Volume II. Hampshire, UK: Ashgate.

Hellweg, U. (2008). Foreword. Cities and climate change. The IBA as a laboratory for urban energy and climate protection concepts. In O. Bartels, O. Hamm (Eds.). Metropole. Ressourcen = Metropolis : Resources. Berlin, Germany: J OVIS Verlag (Metropole, v. 2), pp. 6- 11. 
Hendriks, F. (2006). Shifts in Governance in a Polycentric Urban Region: The Case of the Dutch Randstad. In International J ournal of Public Administration 29 (10-11), 931- 951.

Heurkens, E. (2012). Private sector-led urban development projects. Management, partnerships \& effects in the Netherlands and the UK. Delft: Delft University of Technology, Faculty of Architecture (A+BE Architecture and the Built Environment, 4).

Heurkens, E., Adams, D., Hobma, F. (2015). Planners as market actors: the role of local planning authorities in the UK's urban regeneration practice. In Town Planning Review 86 (6), 625- 650.

Heurkens, E., Hobma, F. (2014). Private Sector-led Urban Development Projects: Comparative Insights from Planning Practices in the Netherlands and the UK. In Planning Practice \& Research 29 (4), 350- 369.

Hjøllund, T., Bøldt, J ., Hendriksen, N., Sieverts Nielsen, P. (2014). Urban Transform EU: Copenhagen, Nordhavn - Implementation Plan. Available online at http:/ / urbantransform.eu/ wp-content/ uploads/ sites/ 2/ 2015/ 07/ D4.2-Copenhagen.pdf.

Hobma, F (2011). Successful urban area development. In Franzen, A., Hobma, F., De J onge, H. \&Wigmans, G. (Eds.). Management of urban development processes in the Netherlands: Governance, design, feasibility, pp. 219-237.

Hodge, G., Greve, C. (2010). Public-Private Partnerships: Governance Scheme or Language Game? In Australian J ournal of Public Administration 69 (2), 8-22.

IBA Hamburg GmbH / Umweltbundesamt / TU Darmstadt (2015). Energieatlas Werkbericht 1. Zukunftskonzept Erneuerbares Wilhelmsburg. Berlin, Germany: J ovis Berlin (Metropole, Sonderband).

IBA Hamburg GmbH (2007). IBA-Exzellenz - die sieben Qualitätskriterien eines IBA-Projekts. Available online at http:/ / www.iba-hamburg.de/ fileadmin/Die_IBA-Story_post2013/ IBA-Exzellenzkriterien.pdf, checked on 10/ 16/2017.

IBA Hamburg GmbH (Ed.) (2007). Reflexionen. With assistance of Oliver G. Hamm. Berlin, Germany: J ovis (Metropole, 1).

Islar, M., Busch, H. (2016). "We are not in this to save the polar bears!" - the link between community renewable energy development and ecological citizenship. In Innovation: The European J ournal of Social Science Research 29 (3), 303- 319.

J anssen-J ansen, L., Lloyd, G., Peel, D., Van der Krabben, E. (2013). Planning in an environment without growth. Invited essay for the Raad voor Infrastructuur en de Leefomgeving (RLI), the Netherlands. Den Haag, netherlands: Raad voor Infrastructuur en de LeefomgevingKassim, H., Le Galès, P. (2010). Exploring Governance in a Multi-Level Polity: A Policy Instruments Approach. In West European Politics 33 (1), 1- 21.

Katz, B., Noring, L. (2017). The Copenhagen City and Port Development Corporation: A Model for Regenerating Cities. Washington DC, USA: Brookings Institution Press.

Klotz, C. (2014). "Strategische Kreativplanung" der Stadt. Die Internationale Bauausstellung IBA Hamburg. Berlin, Germany: De Gruyter (Urban Studies). 
Lascoumes, P., Le Galès, P. (2007). Introduction: Understanding Public Policy through Its Instruments?From the Nature of Instruments to the Sociology of Public Policy Instrumentation. In Governance 20 (1), 1- 21.

Magalhães, C. (2001). International property consultants and the transformation of local markets. In J ournal of Property Research 18 (2), 99- 121.

Majoor, S., Schwartz, K. (2015). Instruments of Urban Governance. In Gupta, J ., Pfeffer, K., Verrest, H., Ros-Tonen, M. (Eds.). Geographies of Urban Governance. Cham, Germany: Springer International Publishing, pp. 109- 126.

Mensink, J ., Franzen, A. (2013). Gebiedsontwikkeling met een ontwikkelpartner, Dosssier Rijswijk Zuid, Praktijkleerstoel Gebiedsontwikkeling TU Delft, Programmabureau RijswijkBuiten, Deloitte Real Estate Advisory en Dura Vermeer Bouw Zuid West BV.

Miles, M., Huberman, M., Saldana, J . (2014). Qualitative data analysis. A methods sourcebook. Edition 3. London, UK: Sage.

Mintzberg, H., Ahlstrand, B. \& Lampel, J (1998). Strategy Safari. Hertfordshire, UK: Prentice Hall.

Mulugetta, Y., J ackson, T., van der Horst, D. (2010). Carbon reduction at community scale. Energy Policy, (38), 7541- 7545.

Needham, B. (2000). Spatial planning as a design discipline: a paradigm for Western Europe? Environment and Planning B: Planning and Design, 27, 437- 453.

Oteman, M., Wiering, M., Helderman, J . (2014). The institutional space of community initiatives for renewable energy: a comparative case study of the Netherlands, Germany and Denmark. In Energ Sustain Soc 4 (1), 11.

Petersen, J -P. (2018). The application of municipal renewable energy policies at community scale in Denmark: A taxonomy of implementation challenges. In Sustainable Cities and Society (38), 205-218.

Petersen, J -P., Quitzau, M-B. (2018). Strategic intelligence: effective implementation alignments for energy strategies through urban development projects. Manuscript submitted for publication.

Pierre, J ., Peters, BG. (2012). Urban governance. In: J ohn, P., Mossberger, K., Clarke, S. (eds). The Oxford handbook of urban politics. Oxford, UK: Oxford University Press.

Pressman, J ., Wildavsky, A. (1973). Implementation. Berkeley, USA: University of California Press.

Rasmussen, A.F. (2006). Prime Minister Anders Fogh Rasmussen's Opening Address to the Folketing (The Danish Parliament) on Tuesday 3 October 2006, available online: http://www.stm.dk/_p_12770.html (accessed 08-102017).

Rose, R. (1993). Lesson-Drawing in Public Policy: A Guide to Learning Across Time and Space. Cambridge, UK: Cambridge University Press.

Rutherford, J ., Coutard, O. (2014). Urban Energy Transitions: Places, Processes and Politics of Socio-technical Change. In Urban Studies 51 (7), 1353- 1377.

Rydin, Y. (2010). Governing for sustainable urban development. London, UK: Earthscan.

Scheffler, N. (2015). Cities tackling climate change: the case of the International Building Exhibition (IBA) Hamburg. In: Sustainable regeneration in urban areas. urbact ii capitalisation, april 2015. Saint Denis, France. Available 
online at https:/ / www.academia.edu/ 28646024/ Sustainable_regeneration_in_urban_areas.

Schneider, A., Ingram, H. (1990). Behavioral Assumptions of Policy Tools. In The J ournal of Politics 52 (2), 510- 529.

Schroeder, H., Burch, S., Rayner, S. (2013). Novel Multisector Networks and Entrepreneurship in Urban Climate Governance. In Environ Plann C Gov Policy 31(5), 761- 768.

Sperling, K., Hvelplund, F., Mathiesen, B. V. (2011). Centralisation and decentralisation in strategic municipal energy planning in Denmark. In Energy Policy 39 (3), 1338- 1351.

Spradley, J . (1980). Participant observation. New York, USA: Holt, Rinehart and Winston.

Squires, G., Heurkens, E. (2016). Methods and models for international comparative approaches to real estate development. In Land Use Policy 50, 573581.

Stoeglehner, G., Narodoslawsky, M. (2013). Integrated Optimization of Spatial Structures and Energy Systems. In S. Stremke, A. Dobbelsteen (Eds.). Sustainable energy landscapes. Designing, planning, and development. Boca Raton, Fla: CRC Press (Applied ecology and environmental management).

Van der Krabben, E., Heurkens, E. (2015). A search for alternative public-private development strategies from neighbouring countries. In Graham Squires (Ed.). International approaches to real estate development. London, UK: Routledge.

Van Waarden, F. (2002). Dutch Consociationalism and Corporatism: A Case of Institutional Persistence. Acta Politica 37(1/2; special issue), 44- 68.

Vergragt, P., Akenji, L., Dewick, P., (2014). Sustainable production, consumption, and livelihoods: global and regional research perspectives. J . Clean. Prod. (63), 1-12.

Waterhout, B., Othengrafen, F., Sykes, O. (2013). Neo-liberalization Processes and Spatial Planning in France, Germany, and the Netherlands: An Exploration. In Planning Practice \& Research 28 (1), 141- 159. 